\title{
Microstructure and Property of Thermal Insulation Coating on the Carbon Fiber Reinforced Epoxy Resin Composites
}

\author{
PAN Bichen ${ }^{1}$, REN Penghe ${ }^{2}$, ZHOU Tejun ${ }^{1}$, CAI Zhenyang ${ }^{2,3}$, ZHAO Xiaojun ${ }^{2,3}$, \\ ZHOU Hongming ${ }^{2,3}$, XIAO Lairong ${ }^{2,3}$
}

(1. State Key Laboratory of Disaster Prevention \& Reduction for Power Grid Transmission and Distribution Equipment, State Grid Hunan Electric Power Company Limited Disaster Prevention \& Reduction Center, Changsha 410029, China; 2. School of Materials Science and Engineering, Central South University, Changsha 410083, China; 3. Key Laboratory of Nonferrous Metal Materials Science and Engineering, Ministry of Education, Central South University, Changsha 410083, China)

\begin{abstract}
A lightweight, environmentally-friendly thermal insulation coating was experimentally applied to the carbon fiber to reinforce epoxy resin composites. The coating is mainly composed of bonding layer, barrier layer and reflective layer, and prepared by using titanium dioxide, silica, aluminum oxide and hollow glass microspheres as function fillers. The addition of waterborne polyurethane with a thermal expansion coefficient of $120 \times 10^{-6} \mathrm{~K}^{-1}$ as a film-forming material, is to solve the problem of cracking caused by the mismatch of the thermal expansion coefficients of the coating and the substrate material. The results show that after being applied, the coating can solidify within $24 \mathrm{~h}$ at room temperature. When the thicknesses of the bonding layer, the heat barrier layer and the reflective layer were 80,120 , and $90 \mu \mathrm{m}$, the thermal insulation coating has the best performance with reflectance of the coating higher than 0.95 , the thermal conductivity at $0.048 \mathrm{~W} \cdot \mathrm{m}^{-1} \cdot \mathrm{K}^{-1}$ and the temperature difference as high as $20.1{ }^{\circ} \mathrm{C}$. After being subjected to thermal shock at $190{ }^{\circ} \mathrm{C}$ for 6 times, and the maximum weight loss rate of the coating was 3.7\%, indicating the coating highly stable. When kept at $160{ }^{\circ} \mathrm{C}$ for $4 \mathrm{~h}$, its surface turned yellow without falling off, and its nano filler particles still remained stable.
\end{abstract}

Key words: thermal insulation coating; titanium dioxide; hollow glass microspheres; carbon fiber reinforced epoxy resin composites

Due to high reliability, low maintenance cost and adaptation to a variety of complex and harsh environments, unmanned aerial vehicle (UAV) has become an important tool for environment preservation, geographical mapping, natural disaster monitoring, fire investigation and relief ${ }^{[1]}$. Carbon fiber reinforced epoxy resin (CFRP) composite is an attractive material for the UAV fuselage, and its working temperature generally was below $160{ }^{\circ} \mathrm{C}^{[2]}$. When the service temperature exceeds $160{ }^{\circ} \mathrm{C}$, the epoxy resin would be softening, resulting in a decrease in the tensile strength and structural stability ${ }^{[3]}$. However, it is a fact that the working environment of fire UAV was often above $160{ }^{\circ} \mathrm{C}$. In order to prevent the actual temperature of CFRP in fire UAV, it is necessary to fabricate a thermal insulation coating on the fuselage surface to ensure the safe operation of the UAV.

According to the different insulation mechanisms, thermal insulation coatings could be divided into radiation thermal insulation coating, barrier-type thermal insulation coating and reflective thermal insulation coating $^{[4]}$. The radiation thermal insulation coating reduced the temperature by emitting absorbed energy into the air at a fixed wavelength. However, the complex sintering process and the unstable effect seriously limited its further application ${ }^{[5]}$. By introducing the substance with low thermal conductivity, a loose porous structure such as a large amount of convection-free air would be presented in the barrier-type thermal insulation coating, which could significantly reduce the heat transfer efficiency ${ }^{[6]}$. Yang, et $a l^{[7]}$ used hollow glass microsphere (HGM) and

Received date: 2019-10-17; Revised date: 2020-01-06

Foundation item: National Natural Science Foundation of China (51901252, U1637210); Key Scientific and Technological Projects of State Grid Corporation of China (SGHNFZ00ZHJCJS1900024)

Biography: PAN Bichen (1991-), male, Master, assistant engineer. E-mail: 457521718@qq.com

潘碧宸(1991-), 男，硕士，助理工程师. E-mail: 457521718@qq.com

Corresponding author: XIAO Lairong, professor. E-mail: xiaolr@csu.edu.cn 肖来荣, 教授. E-mail: xiaolr@csu.edu.cn 
phenolic resin to prepare a composite material with a thermal conductivity of $0.1024 \mathrm{~W} \cdot \mathrm{m}^{-1} \cdot \mathrm{K}^{-1} . \mathrm{Hu}$, et $a l^{[8]}$ developed a HGM double-layer coating using oxide (ATO) and $\mathrm{TiO}_{2}$, with a low thermal conductivity of $0.05 \mathrm{~W} \cdot \mathrm{m}^{-1} \cdot \mathrm{K}^{-1}$. The reflective thermal insulation coating exhibited a high reflectance in a large range of light wavelength by the addition of the highly reflective fillers such as titanium dioxide, zinc oxide, and rare earth oxides $^{[9]}$. Li, et al ${ }^{[10]}$ synthesized a series of environmentally nontoxic near-infrared reflective pigments of $\mathrm{BiVO}_{4}$ coated mica-titanium oxide, whose NIR reflectance is up to 0.92 . Zhu, et al ${ }^{[11]}$ prepared a coating on aluminum plate with carbon black, fluorinated acrylic resin emulsion and a small number of $\mathrm{SiO}_{2}$ nanoparticles silicon resin emulsion, whose temperature difference and reflectivity could be up to $30{ }^{\circ} \mathrm{C}$ and $68 \%$, respectively.

By combining highly reflective materials with low thermal conductivity materials, a portion of the thermal insulation coating has both high reflectivity and low thermal conductivity. Wang, et $a l^{[12]}$ prepared silicone acrylic emulsion coating containing different dosages of ATO microspheres on glass, with a low thermal conductivity of $0.128 \mathrm{~W} \cdot \mathrm{m}^{-1} \cdot \mathrm{K}^{-1}$ and a high infrared emissivity of 0.974 . Long, et al ${ }^{[13]}$ used $\mathrm{TiO}_{2} / \mathrm{HGM}$ composite pigments to fabricate a thermal insulation coating on aluminum board and found that the reflectance was 0.96 , and the temperature difference was $22.4{ }^{\circ} \mathrm{C}$. However, to the authors' knowledge, there are few reports on both of thermal insulation coatings and barrier-type thermal insulation coatings applied to carbon fiber reinforced epoxy composites. The questions whether and what extent the combinational coating can effectively improve the heat resistance, remained. The aim of this work was, therefore, to develop a new type of lightweight thermal insulation coating on carbon fiber reinforced epoxy resin composites to solve the heat cracking caused by the expansion of base material and achieve both low thermal conductivity and high reflectivity, evaluate their microstructure and thermal properties, and identify the failure behavior.

\section{Experimental}

\subsection{Materials and experiments}

In the present work, to fabricate a thermal insulation coating, the waterborne polyurethane was used as filmforming material, and hollow glass microspheres, titanium dioxide, silicon dioxide and aluminum oxide were used as fillers. Carbon fiber reinforced epoxy resin composites with a thermal expansion coefficient of $30 \times$ $10^{-6} \mathrm{~K}^{-1}$ and a glass transition temperature of $160{ }^{\circ} \mathrm{C}$ were used as base material. To prepare layer-slurry bonding, $\mathrm{TiO}_{2}$ and waterborne polyurethane were thoroughly mixed for $2 \mathrm{~h}$ using ethanol and dispersant as milling medium. To prepare barrier layer slurry, hollow glass microspheres, $\mathrm{TiO}_{2}$, and polyurethane were thoroughly mixed, using water and dispersant as milling medium. To prepare reflective layer slurry, the silica aerogel, the sodium silicate solution, titanium dioxide, silicon dioxide and aluminum oxide were sequentially added to the reaction kettle with stirring. Additionally, the base material was cleaned with distilled water and ethanol. Then, the bonding slurry, barrier slurry and reflective slurry were sequentially sprayed on the base materials. Finally, the cured coating was achieved after drying at room temperature for $24 \mathrm{~h}$.

\subsection{Characterization}

The thickness of thermal insulation coating was tested by film thickness tester (Filmetrics). The reflectivity and thermal conductivity of thermal insulation coatings were measured using a spectrophotometer (V-1300) and a heat conduction analysis meter (ZDJR-3). The temperature difference of thermal insulation coating was observed via insulation film temperature tester (SXLD-9). The microstructures of the thermal insulation coating were examined using scanning electron microscopy (QTA-200). The thermal insulation coating was heat-treated using a blast drying oven (DHG-9050A). The weight loss of the coating was measured by an incubator and an anatical balance, and a thermal cycle is $30 \mathrm{~min}$. The micro characterization was performed using transmission electron microscopy $(\mathrm{G} 20)^{[14]}$.

\section{Results and discussion}

\subsection{Designed microstructure of the thermal insulation coating}

Fig. 1(a) shows the designed microstructure of the thermal insulation coating. It is clear that, in order to improve the adhesion and thermal insulation property of coating, the thermal insulation coating is designed with three functional layers including bonding layer, barrier layer and reflective layer. Due to the difference in thermal expansion coefficient between base material and coating, the expansion of the base material should be much larger than coating. After heating, there are likely to be large compressive stresses in the coating which cause the coating to buckle and flake off, a process known as spalling ${ }^{[15]}$. Therefore, the bonding layer was introduced on carbon fiber reinforced epoxy resin composites in present work. Since the thermal expansion coefficients of epoxy resin and $\mathrm{TiO}_{2}$ are $120 \times 10^{-6}$ and $9 \times 10^{-6} \mathrm{~K}^{-1}$, respectively. Hence, the polyurethane with the thermal expansion coefficient of $30 \times 10^{-6} \mathrm{~K}^{-1}$ was used to inhibit 
the heat cracking ${ }^{[16]}$. In order to reduce the thermal conductivity of thermal insulation coating, the barrier layer with a specific cavity structure were prepared on bonding layer, using hollow glass microspheres as main filler. Additionally, after being cured, there are a large number of gaps between the hollow microspheres in the thermal insulation coating, leading to a certain decrease in the impermeability and adhesion of the coating. Therefore, polyurethane was added in the barrier layer to fill the gap of hollow microspheres and improve the density, water resistance and adhesion ${ }^{[17]}$. The barrier layer made of hollow glass microspheres has a disadvantage of low reflectance and many surface defects; therefore, the reflective layer made of $\mathrm{TiO}_{2}, \mathrm{SiO}_{2}$ aerogel, $\mathrm{Al}_{2} \mathrm{O}_{3}$ was introduced to give the thermal insulation coating a high reflectivity and a good surface quality without micropore and micro-cracks.

A dense and flat surface were presented in the bonding layer (Fig. 1(b)), without obvious defects such as looseness and micro-cracks. However, due to a large difference in particle size between hollow glass microspheres and $\mathrm{TiO}_{2}$, the surface of barrier layer with a small number of broken particles and micro holes were observed as shown in Fig. 1(c). Furthermore, due to a lot of nano-particles addition such as $\mathrm{TiO}_{2}, \mathrm{SiO}_{2}$ and $\mathrm{Al}_{2} \mathrm{O}_{3}$, a dense surface without obvious defect could be found in reflective layer as shown in Fig. 1(d).

\subsection{Thickness optimization of the designed functional layers}

The thermal expansion coefficients of carbon fiber reinforced epoxy resin composites, $\mathrm{TiO}_{2}$ and polyurethane are $30 \times 10^{-6}, 9 \times 10^{-6}$, and $120 \times 10^{-6} \mathrm{~K}^{-1}$, respectively. In
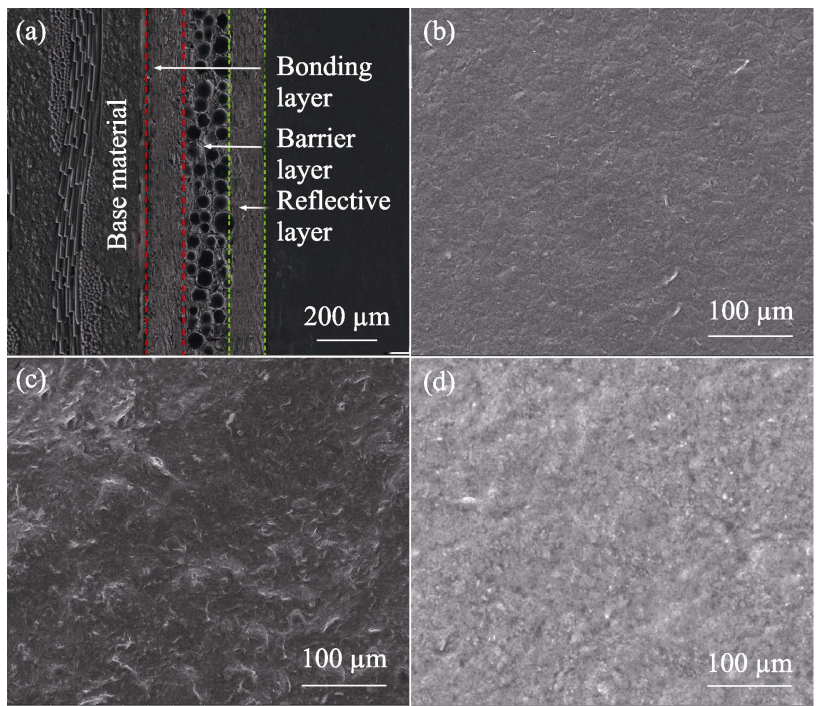

Fig. 1 Designed microstructure of the thermal insulation coating

(a) Cross section; (b) Bonding layer surface; (c) Barrier layer surface; (d) Reflective layer surface order to match the thermal expansion between base material and the coating, $\mathrm{TiO}_{2}$ was mixed with polyurethane in the bonding layer. Thickness of the bonding layer was an important factor in ensuring the service time at the actual temperature. Fig. 2(a) shows the effect of bonding layer thickness on service time at 160 and $190{ }^{\circ} \mathrm{C}$. With the coating thickness increasing, the service time marked increased. Furthermore, when thickness of bonding coating remained constant, the service time remarkably decreased with the increase of the service temperature. At a coating thickness of $80 \mu \mathrm{m}$, the time required for shedding reach 360 and $200 \mathrm{~min}$. Continuous growth in coating thickness has little effect on coating shedding. Therefore, the thickness of the bonding layer is designed to be $80 \mu \mathrm{m}$ or more.
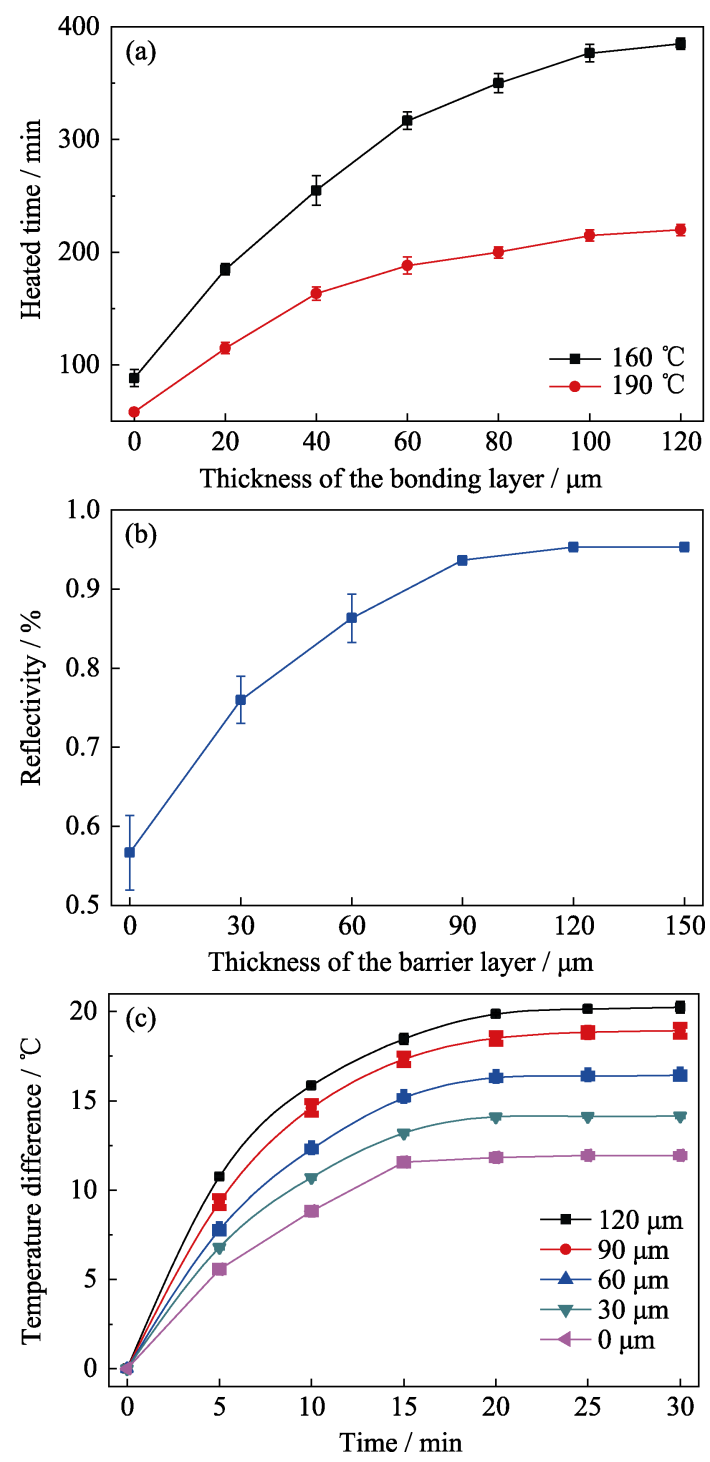

Fig. 2 Thickness optimization of the designed functional layers

(a) Time required for coating to fall off at 160 and $190{ }^{\circ} \mathrm{C}$; (b) Reflectivity of coatings with different thicknesses of reflective layers; (c) Temperature difference change curves for coatings with different thicknesses of the barrier layer 
Fig. 2(b) shows the reflectivity as a function of the reflective layer thickness. When the coating thickness reached up to $90 \mu \mathrm{m}$, the coating reflectivity increased obviously with the increase of the coating thickness. A further increase of coating thickness from $90 \mu \mathrm{m}$ to $150 \mu \mathrm{m}$ only gave rise to a slight increase. The reflection performance of the coating is related to the thickness of the surface layer, and simply increasing the thickness of the coating does not continuously increase the reflectance. Consequently, the optimum thickness of the reflective layer is about $90 \mu \mathrm{m}$.

The thickness of the barrier layer is determined on the basis of the thicknesses of the bonding layer and reflective layer. Fig. 2(c) shows the temperature difference of thermal insulation coatings as a function of the barrier layer thickness, where the thickness of bonding layer and reflective layer were $80 \mu \mathrm{m}$ and $90 \mu \mathrm{m}$, respectively. The temperature difference of the coatings increased with the increase of the holding time. Additionally, it is clear that, the thicker the coating thickness, the longer the temperature stabilize time turns. When the thickness of coating increased from $170 \mu \mathrm{m}$ to $320 \mu \mathrm{m}$, the stabilized time would be prolonged from $15 \mathrm{~min}$ to $20 \mathrm{~min}$. The fast-rising zone ranged from $0 \mu \mathrm{m}$ to $120 \mu \mathrm{m}$, and the thermal insulation temperature difference is rapidly increased from $12{ }^{\circ} \mathrm{C}$ to $20.1{ }^{\circ} \mathrm{C}$. This huge increase comes from the increase in coating thickness and the decrease in the thermal conductivity of the coating. The stable rising zone range is above $120 \mu \mathrm{m}$, and the increase in the thermal insulation temperature difference is mainly due to the increase in coating thickness. Considering the overall performance of the coating, $120 \mu \mathrm{m}$ is the best choice for the barrier layer.

\subsection{Property of the thermal insulation coating}

To examine the thermal cycling performance of fabricated thermal insulation coating, the weight-loss rate per cycle between $100{ }^{\circ} \mathrm{C}$ and $190{ }^{\circ} \mathrm{C}$ of the specimens was measured. A similar characteristic could be seen in all of the coating weight-loss curve exhibits under different temperatures. In the first two cycles, the weight-loss rate of the coating is rapidly increased. This can be mainly related to the volatilization of small molecules. However, when the thermal cycle further increasing, only a slight increase was observed. With room-temperature curing, the coating can reach as thick as $300 \mu \mathrm{m}$ and some of the small-molecule solvents or auxiliaries are not entirely volatilized $^{[18]}$. In the subsequent multiple cycles, the coating did not substantially lose weight, indicating good thermal stability and effectively adapted to the thermal cycle environment. Also, the carbon fiber reinforced epoxy resin composites are used as the base material, and their heat-resistance temperature is only $130{ }^{\circ} \mathrm{C}$. At

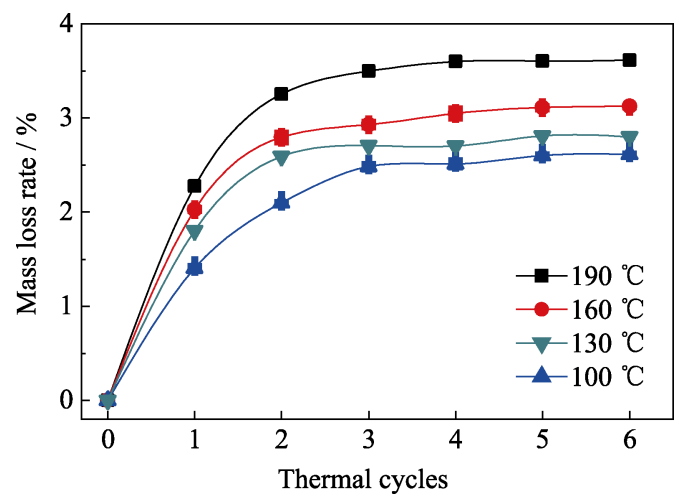

Fig. 3 Weight loss curves of the thermal insulation coatings at different temperatures

$190{ }^{\circ} \mathrm{C}$, the growth of weight loss rate was relatively faster, eventually reached $3.7 \%$. This weight loss can be attributed to the matrix material; however, the coating's weight subsequently remained stable. The aforementioned results show that the coating exhibits high thermal stability and can be effectively used in a wide range of temperature conditions.

The macroscopic morphology of the thermal insulation coatings heated at $160{ }^{\circ} \mathrm{C}$ for $0,1,2$, and $4 \mathrm{~h}$ are shown in Fig. 4. Their coating and substrate material were unchanged when temperature was maintained at $160{ }^{\circ} \mathrm{C}$ for $1 \mathrm{~h}$. If this temperature was maintained for $2 \mathrm{~h}$, their surface of the coating material turned slightly yellow. Further, when the temperature was maintained for $4 \mathrm{~h}$, the surface of the coating exhibited a uniform light orange color. After heat preservation at $160{ }^{\circ} \mathrm{C}$ for 1,2 , and $4 \mathrm{~h}$, the coating materials can effectively protect

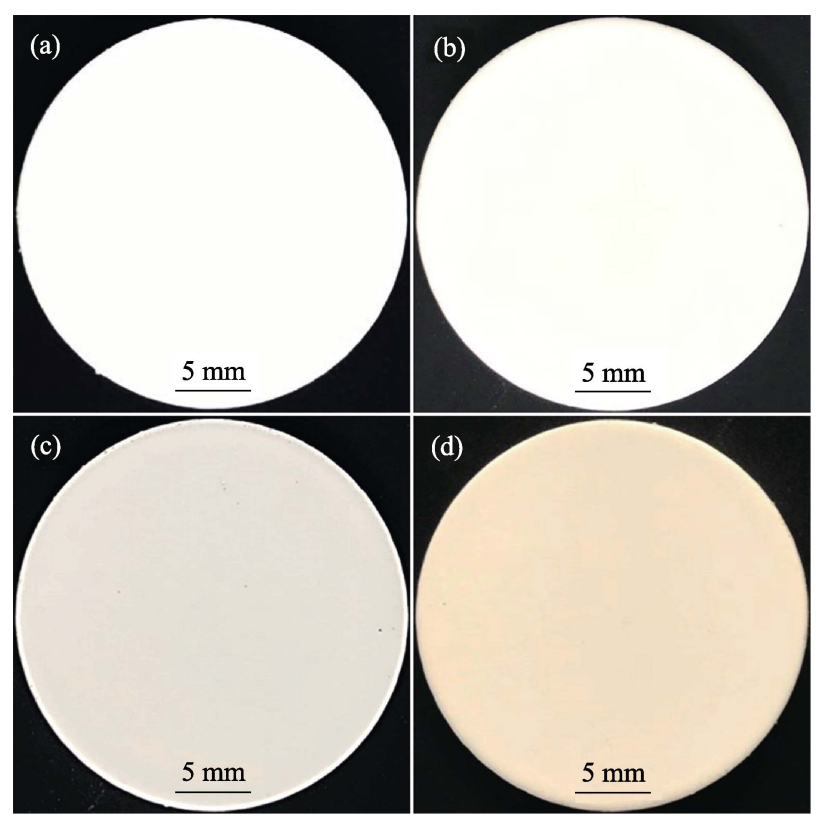

Fig. 4 Macroscopic morphology changes of the coatings when heated at $160{ }^{\circ} \mathrm{C}$ for different time (a) $0 \mathrm{~h}$; (b) $1 \mathrm{~h}$; (c) $2 \mathrm{~h}$; (d) $4 \mathrm{~h}$ 


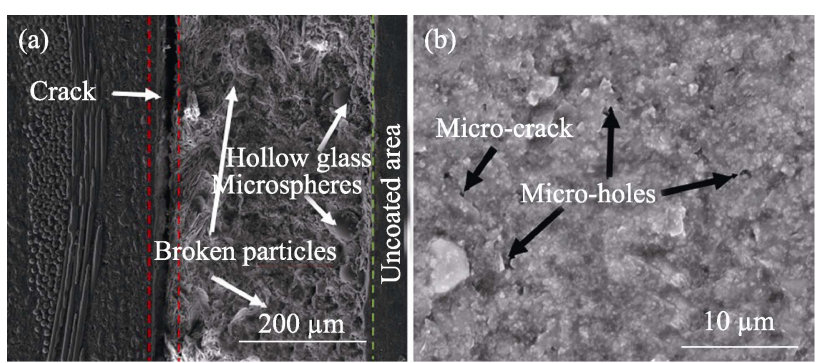

Fig. 5 SEM morphology changes of coatings heated at $160{ }^{\circ} \mathrm{C}$ for $4 \mathrm{~h}$

(a) Coating cross-section; (b) Reflective layer surface

the substrate from failure, indicating good high-temperature insulation performance and that the addition of polyurethane in bonding layer effectively matches the amount of expansion of the base material and reduces thermal stress.

\subsection{Failure behaviors of the thermal insulation coating}

As shown in Fig. 5(a), due to the polyurethane added to the thermal insulation coating, there was some degree of embrittlement in the coating. In the cross section, cracking occurs between the coating and the base material. The coating fails and falls off when the transverse cracks expand and contact each other. This failure phenomenon can be mainly attributed to the difference between the thermal expansion coefficients of the base and the coating materials. During the extended heating process, different degrees of expansion can be observed, resulting in stress at the base and coating cross section. There is a little bit of micro holes on the coating surface after being heated at $160{ }^{\circ} \mathrm{C}$ for $4 \mathrm{~h}$ (Fig. 5(b)).

Fig. 6 shows the morphology of nano-particles before and after the coatings were heated at $160{ }^{\circ} \mathrm{C}$ for $4 \mathrm{~h}$. It can be seen that all $\mathrm{TiO}_{2}$ particles were nano-sized $(<100 \mathrm{~nm})$, but there also appeared a conglomeration because it was rather difficult to disperse nanometer powders on the copper plate after ultrasonic vibration for TEM imaging ${ }^{[19]}$. Furthermore, it is clear that, although the coating was heated at $160{ }^{\circ} \mathrm{C}$ for $4 \mathrm{~h}$, no obvious change in nano-sized particles including uniformly mixed with the $\mathrm{SiO}_{2}$ and $\mathrm{Al}_{2} \mathrm{O}_{3}$ particles could be observed. It is suggested that the structure of $\mathrm{TiO}_{2}$ and $\mathrm{Al}_{2} \mathrm{O}_{3}$ powders in the present study was thermally stable enough after being heated at $160{ }^{\circ} \mathrm{C}^{[20]}$.

\section{Conclusions}

In order to prevent the actual temperature of CFRP in fire UAV, a new type of thermal insulation coating has been achieved. The coating included bonding layer, heat insulating layer and reflective layer, with optimal thickness of about 80,120 , and $90 \mu \mathrm{m}$, respectively.
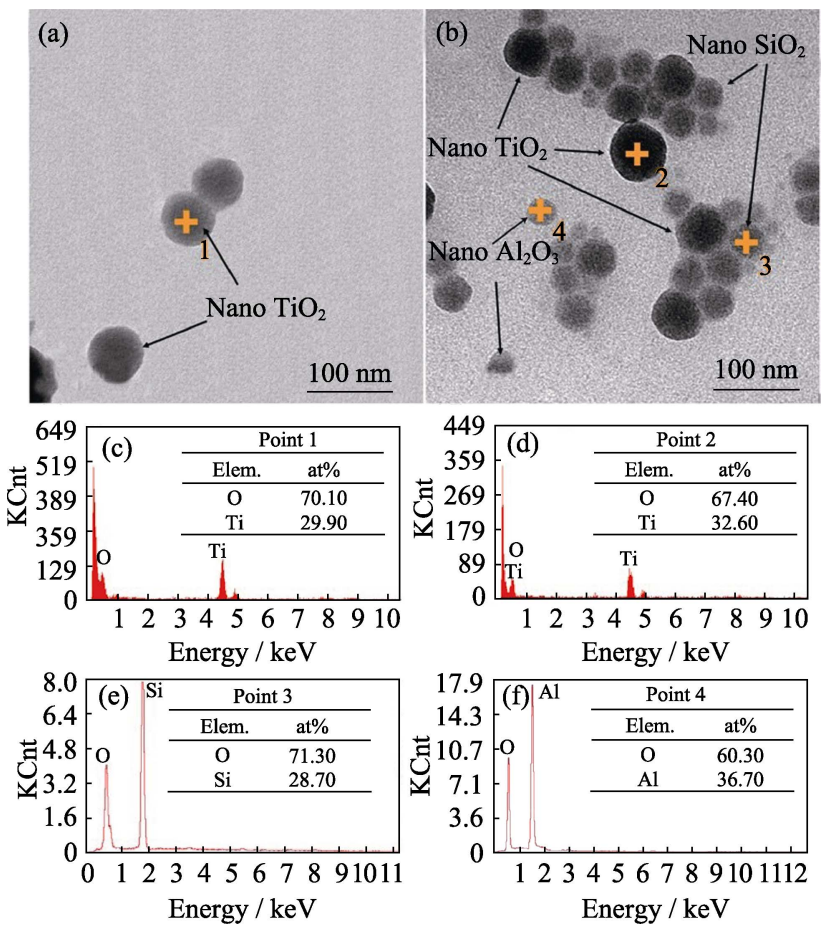

Fig. 6 TEM iamges of nonmetric $\mathrm{TiO}_{2}$ in coatings (a) before and (b) after being heated and corresponding EDS of (c) point 1, (d) point 2, (e) point 3, and (f) point 4 in (a) and (b)

The designed thermal insulation coating solves the problem of bonding between the coating and the base material, while having a low thermal conductivity of $0.048 \mathrm{~W} \cdot \mathrm{m}^{-1} \cdot \mathrm{K}^{-1}$ and a high reflectivity of 0.95 . On this basis, the comprehensive performance of the thermal insulation coating is characterized as follows: the thermal insulation temperature difference is up to $20.1{ }^{\circ} \mathrm{C}$; the thermal insulation coating was subjected to thermal shock at $190{ }^{\circ} \mathrm{C}$ for 6 times, the highest weight loss rate was just 3.7\%. Therefore, the thermal insulation coating can work continuously at $160{ }^{\circ} \mathrm{C}$ for $4 \mathrm{~h}$.

\section{References:}

[1] ESFAHLANI S S. Mixed reality and remote sensing application of unmanned aerial vehicle in fire and smoke detection. Journal of Industrial Information Integration, 2019, 15: 42-49.

[2] MA C, QIU S, YU B, et al. Economical and environment-friendly synthesis of a novel hyperbranched poly(aminomethylphosphine oxide-amine) as co-curing agent for simultaneous improvement of fire safety, glass transition temperature and toughness of epoxy resins. Chemical Engineering Journal, 2017, 322: 618-631.

[3] SHAH D B, PATEL K M, JOSHI S J, et al. Thermo-mechanical characterization of carbon fiber composites with different epoxy resin systems. Thermochimica Acta, 2019, 676: 39-46.

[4] GOU W W, CHE X G, YU X J, et al. Facile fabrication of waterborne fabric coatings with multifunctional superhydrophobicity and thermal insulation. Materials Letters, 2019, 250: 123-126.

[5] LIU F S, CHENG X D, MAO J W, et al. Fabrication and characterization of $\operatorname{Pr}_{6} \mathrm{O}_{11}-\mathrm{HfO}_{2}$ ultra-high temperature infrared radiation coating. Journal of the European Ceramic Society, 2019, 39(14): 
$4208-4215$.

[6] GUO F, CHEN X, WANG G, et al. Hollow ceramic microspheres prepared by combining electro-spraying with non-solvent induced phase separation method: a promising feedstock for thermal barrier coatings. Materials \& Design, 2018, 139: 343-350.

[7] YANG H Y, JIANG Y P, LIU H Y, et al. Mechanical, thermal and fire performance of an inorganic-organic insulation material composed of hollow glass microspheres and phenolic resin. Journal of Colloid and Interface Science, 2018, 530: 163-170.

[8] HU Y, ZHONG H, WANG Y H, et al. Development of an antimony doped tin oxide/ $/ \mathrm{TiO}_{2}$, double-layers coated HGM: a high reflectivity and low transmittance building thermal conservation material. Energy Procedia, 2017, 105: 4128-4132.

[9] BRITO FILHOA J P, OLIVERIRA SANTOSB T V. Thermal analysis of roofs with thermal insulation layer and reflective coatings in subtropical and equatorial climate regions in Brazil. Energy and Buildings, 2014, 84: 466-474.

[10] LI Z H, DUAN F F, HUA J S, et al. Preparation of novel heat-resistant phthalonitrile biphenyl-type novolac resin hollow microspheres. Journal of Central South University, 2017, 48(10): 2597-2605.

[11] ZHU C X, LIN W Q, CHEN L D, et al. Deep color, heat-reflective, superhydrophobic and anti-soiling coatings with waterborne silicone emulsion, Solar Energy Materials and Solar Cells, 2019, 199: 129-135.

[12] WANG M J, XU Y, LIU Y, et al. Synthesis of Sb-doped $\mathrm{SnO}_{2}$ hollow microspheres and its application in photo-thermal shielding coating. Progress in Organic Coatings, 2019, 136: 105229.
[13] LONG J, JIANG C W, ZHU J D, et al. Controlled $\mathrm{TiO}_{2}$ coating on hollow glass microspheres and their reflective thermal insulation properties. Particuology, 2020, 49: 33-39.

[14] KIM H J, LEE H J, KIM D S. Hollow $\mathrm{TiO}_{2}$ flake prepared from $\mathrm{TiO}_{2}$ coated glass flake for solar heat protection and their thermal performance. Materials \& Design, 2018, 150:188-192.

[15] MIYAUCHIA K, TAKITAB Y, YAMABEA $\mathrm{H}$, et al. A study of adhesion on stainless steel in an epoxy/dicyandiamide coating system: influence of glass transition temperature on wet adhesion. Progress in Organic Coatings, 2016, 99: 302-307.

[16] LU K L, JI Z G, KONG Z, et al. Preparation and thermal insulating properties of antimony doped nano- $\mathrm{SnO}_{2} /$ waterborne polyurethane composite coatings. Journal of Inorganic Materials, 2012, 27(10): 1217-1220.

[17] DAI Z, LI Z, LI L, et al. Synthesis and thermal properties of antimony doped tin oxide/waterborne polyurethane nanocomposite films as heat insulating materials. Advances in Polymer Technology, 2011, 22(12): 1905-1911.

[18] YUAN L, HAN A J, YE M Q, et al. Preparation, characterization and thermal performance evaluation of coating colored with NIR reflective pigments: $\mathrm{BiVO}_{4}$, coated mica-titanium oxide. Solar Energy, 2018, 163: 453-460.

[19] CHEN Y F, TANG X N, ZHANG B, et al. $\mathrm{TiO}_{2}$ and $\mathrm{SiO}_{2}$ composites: preparation and photocatalytic antimicrobial performance. Journal of Inorganic Materials, 2019, 34(12): 1225-1333.

[20] ZHANG Z, WANG X D, SHEN J. Effect of organic-inorganic crosslinking extent on mechanical and thermal properties of aerogel. Journal of Inorganic Materials, 2020, 35(4): 454-460.

\title{
树脂基复合材料表面隔热涂层的组织与性能研究
}

\author{
潘碧宸 ${ }^{1}$, 任鹏禾 ${ }^{2}$, 周特军 ${ }^{1}$, 蔡圳阳 ${ }^{2,3}$, 赵小军 ${ }^{2,3}$, 周宏明 ${ }^{2,3}$, 肖来荣 ${ }^{2,3}$
}

(1. 国网湖南省电力有限公司防灾减灾中心电网输变电设备防灾减灾国家重点实验室, 长沙 410029; 2 . 中南大学 材料科学与工程学院, 长沙 410083; 3. 中南大学 有色金属材料科学与工程教育部重点实验室, 长沙 410083)

摘 要: 以碳纤维增强环氧树脂作为基体材料, 设计并制备了一种轻质、环保的隔热涂层。为解决基体材料与涂层 之间热膨胀系数差别大导致易于开裂的问题，同时实现具有高反射率和低热导率的目标，通过添加聚氨酯、 $\mathrm{TiO}_{2}$ 、 $\mathrm{SiO}_{2} 、 \mathrm{Al}_{2} \mathrm{O}_{3}$ 等填料制备连接层、阻隔层、反射层等三个不同功能层形成复合隔热涂层。通过优化涂层脱落时间、 反射率、热导率等, 得到连接层、阻隔层、反射层最优厚度分别为 $80 、 120$ 和 $90 \mu \mathrm{m}$ 。优化后的隔热涂层具有优异 性能: 涂层的反射率高达 0.95 , 导热系数为 $0.048 \mathrm{~W} \cdot \mathrm{m}^{-1} \cdot \mathrm{K}^{-1}$, 隔热温差为 $20.1{ }^{\circ} \mathrm{C}$; 耐热冲击性能良好, $190{ }^{\circ} \mathrm{C}$ 的最 大失重率为 $3.7 \%$, 并在随后保持稳定; 在 $160{ }^{\circ} \mathrm{C}$ 连续保温 $4 \mathrm{~h}$ 后表面变黄, 但无明显脱落现象, 同时, 纳米填料颗粒 保持原状态。

关 键 词: 隔热涂层; 二氧化钛; 空心玻璃微球; 碳纤维增强环氧树脂

中图分类号: TQ637 文献标识码: A 